$10-2016$

\title{
Interview with Scott Russell Sanders
}

Follow this and additional works at: https://scholarsarchive.byu.edu/inscape

\section{Recommended Citation}

(2016) "Interview with Scott Russell Sanders," Inscape: Vol. 36 : No. 1 , Article 22.

Available at: https://scholarsarchive.byu.edu/inscape/vol36/iss1/22

This Interview is brought to you for free and open access by BYU ScholarsArchive. It has been accepted for inclusion in Inscape by an authorized editor of BYU ScholarsArchive. For more information, please contact scholarsarchive@byu.edu, ellen_amatangelo@byu.edu. 


\section{Interview with Scott Russel Sanders}

Scott Russell Sanders is the author of twenty books of fiction and nonfiction, including Hunting for Hope and A Conservationist Manifesto. His most recent books are Earth Works: Selected Essays (2012) and Divine Animal: A Novel (2014). His most recent work, a collection of his eco-science fiction stories entitled Dancing in Dreamtime was published last fall, and a new edition of his documentary narrative, Stone Country, co-authored with photographer Jeffrey Wolin, will appear in 2017. Among his honors are the Lannan Literary Award, the John Burroughs Essay Award, the Mark Twain Award, the Cecil Woods Award for Nonfiction, the Eugene and Marilyn Glick Indiana Authors Award, and fellowships from the Guggenheim Foundation and the National Endowment for the Arts. In 2012 he was elected to the American Academy of Arts and Sciences. He is a Distinguished Professor Emeritus of English at Indiana University. He and his wife, Ruth, a biochemist, have reared two children in their hometown of Bloomington, in the hardwood hill country of Indiana's White River Valley.

INSCAPE: How is the essay a particularly good vessel for beauty?

SCOTT RUSSELL SANDERS: All art forms are potential vessels for beauty. Philosophers have debated whether beauty is inherent in reality, or simply a human response to something that resonates with our own nature. I believe there is truth in both views. When we experience beauty - in a human face, a sunset, a poem or piece of music, an 
idea or a mathematical formula, or in any other phenomenon - we're recognizing a quality that exists outside of ourselves. But we're also recognizing an aspect of our own character as perceiving creatures. The universe is saturated with beauty. As microscopes and telescopes extend the range of our perceptions, we find beauty everywhere, in vanishingly small structures and in the depths of space. Along with this pervasive beauty, of course, the cosmos also manifests violence. Every structure generated by the cosmos, from hydrogen atoms and human bodies to stars and galaxies, is eventually dismantled, and its constituents are reassembled into new structures. Even this violence is shot through with beauty — as one can see, for example, in Hubble Space telescope images of supernovas. For me, the essay has proven to be the most effective medium for thinking and writing about these matters, including the link between our own mortality and the way of nature.

INSCAPE: Some of your essays deal with the personal issues of others, even your own family members. I admire the gentle yet honest way you write about them, but when writing about people you are close to, which takes precedent: honesty or kindness? Do you give disclaimers to those people before you write the stories, or does that limit the story you can tell?

SRS: I wish to avoid harming the real people who appear in my work, either by invading their privacy or by writing something they might find hurtful. Following that principle does place limits on what I write about, or at least on what I choose to publish. For instance, while I adored my father, and wrote several essays celebrating his 
character and his gifts, I was also deeply troubled by his alcoholism; but I chose not to write about that dark aspect of his life while he was alive. About five years after he died, I finally wrote an essay called "Under the Influence," about how his drinking had affected me and the rest of the family. Before I showed the essay to anyone else, I gave it to my mother, who didn't believe there was such a disease as alcoholism. She regarded my father's drinking as a moral failure. She was horrified that I had written about this shameful family secret. "If it was useful for you to write this," she told me, "well and good, but don't let anybody else see it." So I put the essay in a drawer, and I would have left it there until after her death, if she hadn't changed her mind. When she told my brother and sister how appalled she was that I had written about "Daddy's problem," they persuaded her to let them read it. So I sent them copies. They found it so helpful that they urged her to let me publish it, so that other people could benefit from it. My mother thought about it, and after a few months she told me I could send it out. It was the first essay I ever sent to Harpers, and to my surprise they chose to publish it.

INSCAPE: I really appreciated "Under the Influence," and how you took the complex, difficult relationship with your father and made it into a moving essay. How do you begin to write something that has taken a lifetime to acquire, and work through? What was the process of putting that struggle on paper, making it an essay?

SRS: As I mentioned earlier, I could not bring myself to write about my father's alcoholism until several years after his death. In "The Inheritance of Tools," written soon after he died, I paid tribute to his 
character and gifts. The essay makes no reference to his drinking, however - not because I consciously avoided the subject, but because I had not yet come to grips with it. I loved him, and I love him still, and I didn't know how to write about this dark side of his character that troubled me and the rest of my family. In "Under the Influence" I was trying to convey what it feels like to be the child of an alcoholic, and, more generally, what it feels like to have a parent who is radically unpredictable because of an addiction or mental illness. A child of such a parent often takes on a sense of responsibility for making things right-for overcoming a mother's depression, perhaps, or a father's unfaithfulness. I felt that responsibility keenly, but of course I couldn't fix what was wrong with my father. While telling a personal story, I wanted to speak more broadly to people who had grown up in a family with a shameful secret. I wanted readers to come away from the essay thinking, not about me, but about their own experiences. Above all, I didn't want readers to feel that I was pitying myself, because I don't for a moment pity myself. I had a wonderful upbringing. If you examine the essay, you'll see that I write about personal matters within larger frameworks-for example, the Bible's treatment of drunkenness, or the role of alcohol in popular culture, or the many slang terms for drinking. As with most of my essays, this one was largely intuitive-not outlined beforehand, not planned in any detail. Before writing an essay, I typically make notes-hunches, images, passages from my reading, memories, cultural data - anything that seems pertinent to an experience or question that haunts me. When the notes reach a certain degree of richness, I search for an opening sentence, set it down, and then I follow where imagination and reflection and language lead. It's a 
process of discovery. Readers like to sense what occasions the writing of an essay, what's at stake for the narrator. In "Under the Influence," what's at stake is the narrator's effort to face and understand the dark side of a father he loves, and to avoid passing on the burden of family secrets to his own son and daughter. While I don't consider writing to be therapy, writing may help one understand more deeply some troubling aspect of one's life, and, in doing so, may alleviate certain kinds of pain or regret or guilt.

INSCAPE: What advice do you have for young writers? Especially those who lack the life experiences that more mature writers can reflect on in their essays?

SRS: The advice I would offer to young writers is what you might expect: Read widely, not only in the essay, and not only work by your contemporaries. When you find a writer who appeals to you strongly, then read his or her work in depth; study it; imitate it; borrow techniques and insights. Creative writing workshops aid in the development of technique; but good writing depends on more than craft; it depends on life experience, knowledge, sustained reflection, lively imagination, and an inquiring intelligence. Essayists tend to produce their best work later than poets or short story writers. But that should not discourage young writers from tackling any question, issue, or body of experience that they find compelling. Even if you don't yet feel capable of doing justice to some powerful experience, write about it anyway, while it's fresh. You can always return to it later, when you may well have gained deeper insight. 
INSCAPE: At your reading you mentioned that you discovered the essay by accident. How did that accidental encounter lead to your success as a writer today? And for that matter, how do you see the personal essay now; what good does the essay offer us?

\$Rి: I've never taken a creative writing class, so what I know about writing is almost entirely derived from reading. Since I was intrigued by the short stories and novels I read in college, I began by writing fiction, and continued in that genre exclusively for about fifteen years. Meanwhile, I had married and become a father, and I was deeply moved by experiences with my young children. Instead of turning those experiences into fiction, I wanted to write about them directly, as if I were recounting a story in a letter to a friend. One of the first such narratives was about carrying my eleven-month-old son in a backpack up a mountain in Oregon, climbing through a layer of clouds to an exposed peak, and feeling terrified. I wrote an account of the hike in an effort to understand the source of that terror. And in the process I made what I came to recognize as a personal essay. I told a true story, rather than an invented one. From high school English classes, I had come to think of the essay as a dull commentary on some abstract subject, such as patriotism or fate. But as I broadened my reading, I discovered a much more vital, inquisitive, and engaging form of the essay-in the work of James Baldwin and Loren Eiseley, for example; in earlier writers such as Henry David Thoreau and John Muir; and in my contemporaries such as Edward Hoagland, Wendell Berry, Annie Dillard, and Barry Lopez. When I began exploring the history of this versatile genre, I pulled from my shelf a leather-bound copy of The Complete Essays 
of Montaigne, which I had received as an academic prize in college. I had scarcely opened the book previously, but now, after stumbling onto the essay, I discovered that this Frenchman had more or less invented the form in the sixteenth century. His work is colorful, cranky, and probing, and it feels contemporary, inviting twentyfirst century readers to reflect on their own lives. In 1981, when I published "Cloud Crossing," the story about carrying my son up the mountain, there were only a few periodicals that even considered personal essays. Among those few were The North American Review and The Georgia Review, both of which became important homes for my writing. Back in 1981, there were no tracks for nonfiction in MFA programs. In fact, there were few MFA programs. Now there are perhaps over a hundred programs and at least as many summer workshops that allow a focus on nonfiction; there are journals and books of criticism devoted to the genre, and there are hundreds of publications, both print and online, that publish essays. Why this upsurge in the writing and reading of personal nonfiction? One reason, I suspect, is the hunger for honest, supple, inquiring use of language. Our culture is poisoned by phony speech, especially on television and the Internet. Commercial, political, and even many religious figures deliver scripted platitudes, ideologies, or outright lies. Personal essays, at their best, offer an antidote to this flaccid or deceitful verbiage.

INSCAPE: With the influx of new nonfiction MFA programs, and nonfiction readers, what is your prediction of the essay's importance and influence in the future? 
SRS: The best essays convey a sense of authenticity, sincerity, and integrity - qualities rare in contemporary American culture. Much of what passes for art today feels shallow and shoddy, like a commodity manufactured for sale rather than something that comes from the heart. That's one reason the essay has gained a wider audience. This audience in turn has encouraged more and more young writers to take up the form, bringing with them a welcome energy and freshness. Like poetry, the essay requires of its audience a higher degree of literacy and a greater effort of comprehension than the mass media require. So it will always be a minority phenomenon. But so long as there are readers and writers who wish to understand their own existence more deeply, and who enjoy following the play of mind through language, they will be drawn to essays.

INSCAPE: What are some nonfiction texts and techniques that you've become an expert on?

SRS: Of the writers whom I named earlier, I learned the most from James Baldwin, Loren Eiseley, Wendell Berry, and Annie Dillard. The civil rights movement was one of the formative experiences of my early years. It made me aware of the monstrous injustice of slavery, and of the continuing blight of racism. Baldwin helped me to see more clearly the legacy of slavery, and to imagine more vividly what African Americans have suffered and are suffering. I was also fascinated by science, and Eiseley helped me see how to draw on scientific insights while telling personal stories. Berry helped me see how to write about place, community, and conservation. Although Dillard and I are contemporaries, she discovered her identity as an 
essayist long before I discovered mine, and she explored the form brilliantly. I felt an immediate kinship with her leaps of imagination, her mystical impulse, and her fascination with the natural world.

INSCAPE: You successfully write in a variety of genres, including Children's books. When you get the inkling to write, how do you choose which genre?

SRS: It's healthy for a writer to be able to work in more than one mode, because no single genre will accommodate every story you may wish to tell. Being able to switch modes - from nonfiction to fiction, say - may also keep your work from becoming stale. For example, I worked for five years on A Private History of Awe, a memoir written while my mother was succumbing to dementia and eventually dying, and while my first born grandchild was entering the world and acquiring the capacities that my mother was losing. It was an arduous project, and when I finished, I restored my energy by turning to fiction, spending most of the next five years writing the novel Divine Animal. Since that book appeared two years ago, I have been writing mostly essays, about daunting issues, such as racial strife and climate disruption. Needing to take a break from contemplating so much damage and suffering, I revised a collection of science fiction stories, which appeared in 2016 as Dancing in Dreamtime. Although I've worked in a range of forms, I have always been exploring the same themes and questions: What does it mean to be human? What is our place in nature? How should we treat one another? How should we treat Earth? 
INSCAPE: Thank you for that. One last question for you: 50 years from now, if only one piece of your work remains, which would it be, why?

SRS: If one of my books survives, I would like it to be Hunting for Hope, which is as close as I have come to articulating my fundamental values. If what survives is a single essay, I would like it to be "Under the Influence." In both cases, the book and the essay, the writing taught me a great deal, and it has proven to be useful to many readers. Both of them have been widely taught, in schools and colleges and graduate programs, and both have elicited voluminous correspondence. If anything I've written is still being read after I'm gone, I hope it will help people live with a bit more insight, purpose, and joy. 